\title{
UCLA
}

UCLA Public Law \& Legal Theory Series

Title

Forms of Deference in Prison Law

Permalink

https://escholarship.org/uc/item/9f56z219

Journal

Federal Sentencing Reporter, 24(4)

Author

Dolovich, Sharon

Publication Date

2012-04-23

Peer reviewed 


\section{Forms of Deference in Prison Law}

It has been almost five decades since the U.S. Supreme Court first opened the courthouse door to prisoner suits, putting paid to the then-prevalent notion that the federal courts had no jurisdiction to hear cases brought by prisoners. ${ }^{2}$ But even during the short-lived "reform" era that followed, the Court took pains to emphasize the need for judicial restraint in this area. ${ }^{3}$ And in the years since, this imperative of restraint-aka deference-has emerged as the strongest theme of the Court's prisoners' rights jurisprudence. 4

It is not unreasonable for courts to grant a measure of deference to state actors tasked with a job as complex, challenging, and hazardous as running the prisons. It does, after all, seem probable that in many cases, what may appear inappropriate to a court far removed from the hothouse of a carceral environment was in fact a reasonable undertaking under the circumstances. It is, however, also the role of the courts to enforce the Constitution, and if that role is not to be abdicated, the need for deference ought not to preclude good faith implementation of constitutional protections.

Of these two imperatives-judicial deference and meaningful constitutional enforcement- the former is arguably the primary driver of the Court's prisoners' rights jurisprudence. Yet taken as a body, the cases in this area reveal no principled basis for determining when deference is justified, what forms it may legitimately take, or the proper limits on its use. Instead, the mere mention of "deference" has emerged as a catch-all justification for curtailing both the burden on prison officials to ensure constitutional prisons and prisoners' prospects for recovery even for arguably meritorious claims.

Deference to prison officials serves at least three main functions in the Supreme Court's prison law cases: it (I) informs the construction of substantive constitutional doctrine, (2) justifies the altering of procedural rules, and (3) frames the interpretation and assessment of relevant facts. In cases involving prisoners' constitutional rights, the Court makes routine and unhesitating use of deference in all these forms to tilt the balance against prisoners. But somewhat unexpectedly, in cases involving the Prison Litigation Reform Act of $1995^{5}$ (PLRA), the signs are more mixed; in particular, one can find instances in which the
Court rejects at least the latter two strategies. Despite the plainly deferential cast of the PLRA's exhaustion requirement, in Jones v. Bock ${ }^{6}$ the Court rejected efforts by the Sixth Circuit to modify the procedural rules governing exhaustion so as to further disadvantage prisoners. And more recently, in Brown v. Plata,7 the Court refused an invitation by Justice Alito in dissent to reframe the procedural history of the case in ways sympathetic to defendants ${ }^{8}$ yet wholly unsupported by the record. As will be seen, both these moves-the Sixth Circuit's crafting of new procedural rules and Justice Alito's creative reading of the record-have analogues in the Court's prisoner's rights jurisprudence, where a general "principle of deference" 9 has prompted the court to recast procedural rules in defendant-friendly terms and to downplay or ignore altogether evidence against the state's position when interpreting the record. Although in neither Jones nor Plata does the Court frame its position in terms of the need for limits on deference, the prison law cases as a body strongly suggest that such limits are necessary if the law in this area is to overcome the impression presently created by the Court's prisoners' rights jurisprudence, that of a skewed process that deprives a whole category of vulnerable citizens of meaningful constitutional protections while only seeming to take their legal claims seriously.

The role of deference in prison law merits a longer and more in-depth treatment than I am able to offer here. This essay is simply a first cut at the issue. As such, it does three things. First, it identifies the three main forms that deference takes in this area and provides examples of the deployment of each in the prisoners' rights cases. Second, it highlights those moments in the PLRA cases where the Court has opted not to defer (thus seeming to reject strategies it freely employs elsewhere), and offers a preliminary hypothesis as to why this might be. Third and finally, it calls for a theory of deference for the prison law context, i.e., for the development of principles to guide judicial deference in prison law cases and to set appropriate limits on its use.

A brief word on terminology: This essay refers variously to the Court's prisoners' rights (or prisoners' constitutional rights) cases and to its prison law cases. The former is intended as a subset of the latter, which encompasses all

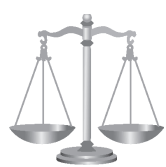

SHARON DOLOVICH ${ }^{1}$

Professor of Law, UCLA School of Law

Federal Sentencing Reporter, Vol. 24, No. 4, pp. 245-259, ISSN I053-9867 electronic ISSN I533-8363. (C) 2012 Vera Institute of Justice. All rights reserved. Please direct requests for permission to photocopy or reproduce article content through the University of California Press's Rights and Permissions website, http://www.ucpressjournals.com/reprintInfo.asp. DOI: IO.I525/fsr.20I2.24.4.245. 
cases involving claims by prisoners. The PLRA cases discussed in Part II constitute another subset of the larger body of case law referred to here as "prison law." And because the cases in question are civil actions brought by prisoner-plaintiffs, the defendants in each instance are prison officials being sued for violations of prisoners' constitutional rights.

\section{Deference in Action}

In cases concerning prisoners' constitutional rights, the imperative of judicial deference takes three main forms. First and most obviously, deference is doctrine-constructing. In this aspect, deference to prison officials is written right into the substantive constitutional standards, yielding rules of decision that tip the scales in favor of defendants. Second, deference is used to justify procedural rule-revising in ways that transform familiar aspects of the legal process into more inherently defendant-friendly procedural mechanisms. Third and finally, deference spurs situationreframing, the recasting of a procedural or factual history in ways that enhance the defendant's position at the plaintiff's expense.

There are many examples of deference operating in each of these ways in the Supreme Court's prisoners' rights cases. The most obvious example of deference in its first, doctrine-constructing form is Turner $v$. Safley. ${ }^{10}$ In Turner, the Court held that prison regulations that burden prisoners' constitutional rights may nonetheless be upheld if they are "reasonably related to legitimate penological interests." "II This holding is itself deferential, creating a space in which prison officials can violate constitutional rights if they can show that doing so facilitates the running of the prison. But the extent to which Turner writes deference into law is clearest in the Court's description of the four factors courts are to use to determine when challenged regulations satisfy the basic Turner standard. The four factors themselves do not necessarily betray a pro-deference slant: courts must ask (I) whether there is a "'valid, rational connection' between the prison regulation and the legitimate governmental interest put forward to justify it"; I2 (2) whether there are "alternative means of exercising the right that remain open to prison inmates"; ${ }^{13}$ (3) what "impact accommodation of the asserted constitutional right will have on guards and other inmates, and on the allocation of prison resources generally"; ;4 and (4) whether there are "ready alternatives" by which prison officials can realize their interests while also affording prisoners the exercise of their rights. ${ }^{15}$

But the Turner Court's elaboration of each of these factors leaves no doubt that the test is intended to be extremely deferential, and provides language for lower courts to draw on to frame this deference as a legal mandate. Thus, the Court explained (I) that "a regulation cannot be sustained where the logical connection between the regulation and the asserted goal is so remote as to render the policy arbitrary or irrational",;6 (2) that "where 'other avenues' remain available for the exercise of the right, courts should be particularly conscious of the measure of judicial deference owed to correctional officers"; ${ }^{\text {I7 }}$ (3) that "in the necessarily closed environment of the correctional institution, few changes will have no ramifications on the liberty of others or on the use of the prison's limited resources"; ${ }^{18}$ and (4) that "if an inmate claimant can point to an alternative that fully accommodates the prisoner's rights at de minimis cost to valid penological interests, a court may consider that as evidence that the regulation does not satisfy the reasonable relationship standard." short, having plainly instructed lower courts that they must be deferential in assessing alternatives (factor 2) and that any change to a prison regime will necessarily have ramifications for the institution (factor 3), the Turner Court made clear that, unless the challenged policy is found to be an "arbitrary or irrational" method for the state to achieve its stated goals (factor I) and claimants can identify an alternative means to "fully accommodate" their rights without any appreciable cost to the prison (factor 4), the challenged regulation is to be upheld. And sure enough, it is a rare case decided under Turner in which the plaintiff ultimately prevails. ${ }^{20}$

Turner, moreover, is hardly the only case that writes deference right into the standards. In Whitley $v$. Albers, ${ }^{21}$ the Court addressed the question of when the use of force by prison officials against prisoners violates the Eighth Amendment. Although previous cases had held that prison officials violate the Eighth Amendment when they are "deliberate[ly] indifferen[t]" to prisoners' basic needs, ${ }^{22}$ Whitley held that use of force against prisoners is only unconstitutional when applied "maliciously and sadistically for the very purpose of causing harm." ${ }^{23}$ Absent a showing of this extremely high (and extremely deferential) mens rea standard, no use of force-however excessive, however unreasonable-will be found unconstitutional. And in Farmer v. Brennan, ${ }^{24}$ the Court defined deliberate indifference as the equivalent of criminal recklessness, thereby protecting prison officials from liability even for conditions, however egregious, about which they should have known but did not. ${ }^{25}$ Farmer framed its holding as necessitated by the language of the Eighth Amendment; in Wilson v. Seiter, ${ }^{26}$ the Court had found that " $[\mathrm{i}] \mathrm{f}$ the pain inflicted is not formally meted out as punishment by the statute or the sentencing judge, some [subjective] mental element must be attributed to the inflicting officer before it can qualify [as punishment]." ${ }^{27}$ But Wilson's reasoning does not stand up to scrutiny, ${ }^{28}$ and once this (pretextual) justification is removed, it is hard not to see Farmer's holding as a product of the Court's determination to create a zone for the exercise of official discretion undisturbed by constitutional imperatives.

Deference also operates in the Court's prisoners' rights cases in the second way noted above, i.e., to justify the altering of existing procedural rules in ways benefiting defendants at plaintiffs' expense. One early example of this form of deference in practice is found in the I977 case of Jones v. North Carolina Prisoners' Labor Union, Inc. ${ }^{29}$ 
At the time, North Carolina permitted prisoners to join a labor union, but imposed rules prohibiting members from holding meetings or from soliciting new members either in person or through bulk mailings from outside the prison. Union members who broke these rules were subject to discipline. Prisoners belonging to the union brought suit, alleging violation of their First Amendment rights of speech and association, and also violation of Equal Protection on the basis that other prisoner organizations were not subject to the same restrictions. $3^{\circ}$ Defendants argued that the restrictions were justified on grounds of prison security-specifically, the concern that some union spokespeople could "establish a power bloc" within the prison that "could be utilized to cause work slowdowns or stoppages or other undesirable concerted activity." ${ }^{1}$ A three-judge panel of the District Court, although crediting the sincerity of defendants' beliefs, also heard expert evidence to the contrary and thus concluded that the "expert opinion evidence" was "conflicting." 32 Noting that "not one scintilla of evidence" had been offered to show that the union had ever interfered with the prison's operations, 33 the panel ultimately found itself unpersuaded by the notion that it was "necessary or essential to security and order in the prisons to forbid solicitation of membership in a union permitted by the authorities." 34 Having thus weighed the testimony in its capacity as finder of fact, the panel found for the prisoners on their First Amendment and Equal Protection claims. 35

The Supreme Court, however, reversed. ${ }^{36}$ Emphasizing "the wide-ranging deference to be accorded the decisions of prison administrators," 37 Justice Rehnquist took issue, not with the substance of the panel's reasoning, but with its approach to weighing the evidence. As Justice Rehnquist put it:

Without a showing that [defendants'] beliefs were unreasonable, it was error for the District Court to conclude that [they] needed to show more. In particular, the burden was not on [defendants] to show affirmatively that the Union would be detrimental to proper penological objectives or would constitute a present danger to security and order. Rather, such considerations are peculiarly within the province and professional expertise of corrections officials, and, in the absence of substantial evidence in the record to indicate that the officials have exaggerated their response to these considerations, courts should ordinarily defer to their expert judgment in such matters..$^{8}$

In other words, although it is ordinarily the job of the trier of fact to hear witness testimony-including expert testimony - and to weigh the evidence presented, Justice Rehnquist made clear that in prison cases, unless there is "substantial evidence" to suggest that officials' response was "exaggerated," courts are to presume the correctness of defendants' assertions. ${ }^{39}$ This mandated deference is more than an acknowledgment that people with expertise in running the prisons are likely to have a deeper understanding of the matter. At trial, the District Court heard direct testimony supporting the prisoners' position from a range of experienced prison administrators, including a Rhode Island prison warden and the Executive Director of the North Carolina Inmate Grievance Commission (and member of the state Sentencing Commission). It also considered documentary evidence from a former Minnesota Corrections director who at the time of trial was Director of Adult Corrections for the state of Delaware. $4^{\circ}$ In other words, experts on both sides had plenty of experience and expertise. But North Carolina Prisoners' Union made it clear that it is the defendants to whom the court should defer, crediting their testimony absent an affirmative "showing that [their] beliefs were unreasonable." It thereby tilted the scales of judicial deliberation strongly toward prison officials at the outset, signaling that defendant prison officials in $\llbracket 1983$ actions brought by prisoners are to be freed from the usual expectation that their own evidence characterizing the situation will be subject to challenge and to meaningful judicial scrutiny.

A more recent example of the altering of established procedural rules for the prisoners' rights context in the name of deference is found in the 2006 case of Beardv. Banks. ${ }^{4 \mathrm{I}}$ In Banks, prisoners held in Pennsylvania's "longterm segregation unit" (LTSU) challenged on First Amendment grounds a policy denying them access to newspapers, magazines, and personal photographs. The District Court, applying the Turner standard, granted summary judgment, and although the Third Circuit reversed, the Supreme Court sided with the District Court. ${ }^{22}$ In particular, a plurality of the Court found "a valid, rational connection" between the challenged policy and the "governmental interest put forward to justify it." 43 According to defendants, the restriction was necessary to "motivate better behavior on the part of particularly difficult prisoners" in the LTSU.44 In finding for defendants, the plurality relied on the testimony of the prison's deputy superintendent, who said in his deposition that incentives for good behavior in the control unit were highly limited and that "the Policy serves to encourage ... progress and discourage backsliding." 45 It appears from the case that Banks had poor representation, ${ }^{46}$ but he nonetheless contested the motion for summary judgment on the grounds that "contact with the world generally favors rehabilitation." 77 For its part, the Third Circuit found insufficient evidence that "the ban was implemented in a way that could modify behavior" or to suggest that the defendants' "deprivation theory of behavior modification had any basis in real human psychology, or had proven effective with LTSU inmates." ${ }^{8}$ And in dissent, Justice Stevens closely scrutinized the government's justification in light of the realities in the unit and made a compelling case on the facts that summary judgment was inappropriate. 49

Because the case involved a grant of summary judgment, the arguments supporting the prisoners' position offered by the Third Circuit and in Justice Stevens's dissent have particular significance. Ordinarily, a grant of 
summary judgment is appropriate only when, taking the evidence in the light most favorable to the non-moving party, the defendants can show that no triable issue of material fact exists..$^{\circ}$ In cases governed by Turner, summary judgment should therefore be denied if there is sufficient evidence on which a jury could find that no "valid, rational connection" existed between the challenged policy and the proffered justifications for it. Arguably, the Court of Appeals offered reason enough to deny the motion: given the lack of supporting evidence for the behavior modification theory, a reasonable jury could well fail to find such a connection in this case. Yet Justice Breyer concluded otherwise. Writing for a plurality of the Court, he found that the Third Circuit placed too high a burden on the defendants, according "too little deference" to the judgment of prison officials about such matters. ${ }^{5 \mathrm{I}}$ This notion may at first seem perplexing: does not the summary judgment standard require courts to "draw all justifiable inferences in favor of the nonmoving party"?52 Maybe in the ordinary case. But when the case involves prisoners, Justice Breyer held, "we must distinguish between evidence of disputed facts and disputed matters of professional judgment." 53 And "[i]n response to the latter, our inferences must accord deference to the views of prison authorities. Unless a prisoner can point to sufficient evidence regarding such issues of judgment to allow him to prevail on the merits, he cannot prevail at the summary judgment stage." 54 In other words, in cases brought by prisoners, before any discovery has even been allowed, plaintiffs must overcome the strong presumption that already exists in favor of the defendants' view of what is necessary to run the prisons, and convince the court not just that a reasonable jury could find in plaintiffs' favor but that it will necessarily do so.

The Banks holding turns the summary judgment standard on its head, clearing the way for defendants to prevail, even in the face of strong opposing arguments, so long as they can provide a colorable argument for their position. As Justice Ginsburg observed in her Banks dissent, defendants' showing in this case-based purely on defendants' own conclusory statements- "is slim, the kind that could be made to justify virtually any prison regulation that does not involve physical abuse." 55 Yet the point of the summary judgment standard, she notes, is to determine whether defendants are "entitled to a judgment as a matter of law." ${ }^{6}$ This conclusion ought only to be reached without trial in cases where no reasonable jury could find otherwise. Yet on the standard as reframed by Justice Breyer, "[i]t suffices for [prison officials] to say, in our professional judgment the restriction is warranted." 57

Third and finally, the imperative of judicial deference operates in prisoners' rights cases to recast relevant facts in ways that deny or disregard the lived experiences of prisoners, thereby undermining the force of the constitutional claim at issue. Some examples: In Rhodes v. Chapman,,$^{8}$ the Court rejected a per se challenge to the practice of double-celling (that is, housing two men in sixty-three-square-foot cells originally intended for one person) as not in itself the "wanton and unnecessary infliction of pain" prohibited by the Eighth Amendment. 59 The Court maintained that no ground existed for an Eighth Amendment claim, since the double-celling did not "create other conditions intolerable for prison confinement." ${ }^{\circ}$ The Court reached this conclusion although the great weight of the evidence indicated that "a longterm inmate must have to himself" a minimum of fifty square feet of floor space "in order to avoid serious mental, emotional, and physical deterioration" - and that, after accounting for the bed alone, even "without making allowance for any other furniture in the room" (e.g., toilet, sink, locker, shelves. etc.), the remaining square footage per person was approximately " $20-24$ square feet, an area about the size of a typical door." ${ }^{6 \mathrm{I}}$ In Whitley $v$. Albers, the Court upheld a directed verdict for defendants on a claim of unconstitutional use of force brought by a prisoner shot by an officer in the course of a prison disturbance. ${ }^{62}$ Writing for the Court, Justice O'Connor emphasized that at the time of the shooting, a riot was in progress, "a guard was still held hostage," and "[t]he situation remained dangerous and volatile." ${ }^{6} 3$ Yet as Justice Marshall noted in dissent, in a case appealing a directed verdict for the defendants, the "facts must be viewed in the light most favorable" to the plaintiff, and in this case, the plaintiff had presented "substantial testimony" at trial to show that by the time the officer shot him, "the disturbance had subsided," that "only one prisoner" —a man named Klenk- "remained in any way disruptive," and that the guard who had been taken hostage in the melee "was not, in fact, in danger," but "had been put into a cell by several inmates to prevent Klenk from harming him." ${ }^{64}$ In Overton v. Bazzetta, ${ }^{65}$ the Court upheld on Turner grounds a two-year ban on visitors for Michigan inmates who had two or more substance abuse infractions. Pursuant to Turner, the Court conceded that, "[w]ere it shown that no alternative means of communication existed, ... . it would be some evidence that the regulations were unreasonable," but then went on to find "communicat[ion] with persons outside the prison by letter and telephone" to be sufficient alternatives. ${ }^{66}$ It thus waved away the seemingly valid concerns that such alternatives are "inadequate for illiterate inmates and for communications with young children" and that "phone calls are brief and expensive," on the telling formalistic grounds that "[a]lternatives to visits need not be ideal," but "need only be available." ${ }^{67}$ And perhaps most striking of all, in Lewis v. Casey, ${ }^{68}$ Justice Scalia maintained that prisoners' right of access to the courts - the right, after Bounds v. Smith, ${ }^{6}$ to "adequate law libraries or adequate assistance from persons trained in the law"7o-entails only the right to "bring to court a grievance that the inmate wished to present." $7 \mathrm{I}$ Justice Scalia's opinion suggested that anything more than access to this narrow extent would be well beyond what the Constitution requires, and he went out of his way to disclaim any 
language in Bounds that might be read to suggest that "the State must enable the prisoner to discover grievances, and to litigate effectively once in court." ${ }^{2}$ Yet as anyone familiar with the legal process is well aware, and as the Bounds Court emphasized, "[i]t would verge on incompetence for a lawyer to file an initial pleading without researching such issues as jurisdiction, venue, standing, exhaustion of remedies, proper parties, [etc.]."73 Moreover, the Bounds Court noted that the state's response to a pro se pleading "will undoubtedly contain seemingly authoritative citations. Without a library, an inmate will be unable to rebut the State's argument." 74 Without legal assistance through the life cycle of a claim, in other words, it is hard to see how a prisoner's right of access to the courts is to have any meaning.

Read separately, there may well be an explanation for the Court's position in each of these cases. A per se ban on double-celling may have been impossible for the states to implement, making such a holding an expenditure of the Court's political capital to no purpose. Finding for the plaintiff in Albers might perhaps have chilled the ability of prison officials to respond adequately to disturbances in their facilities. Striking down the ban on visitation for Michigan prisoners with multiple substance-abuse violations might have deprived the prison of an available incentive for prisoners to avoid drugs and alcohol while in custody. ${ }^{75}$ And making the right of access meaningful over the life cycle of a claim would surely tax prison systems. Yet in none of these cases is the Court forthright about these possible implications, which might have allowed explicit consideration of the legitimacy of allowing such concerns to dictate constitutional outcomes. Instead, in its quest to reach the desired result, the Court simply pretends that the facts as it frames them require the stipulated outcome, reasoning in ways that not only favor defendants but also seem willfully to deny the lived experience of prisoners-even when the nature of that experience is the gravamen of the legal complaint.

In sum, far from achieving a balance between appropriate deference and appropriate constitutional enforcement, the Court's prisoners' rights case law seems instead to be a jurisprudence of evasion, justified by talismanic reference to the need to defer. The overall impression is of an area of constitutional law that preserves the form in each case yet lacks what is arguably the heart of the enterprise: a good faith assessment of each claim in light of applicable constitutional principles, fairly and consistently applied. In an area as fraught as the running of prisons, it may be reasonable at times to create space for the exercise of official discretion. But far from seeking principles for the appropriate scope for discretion, and thus for an appropriately calibrated deployment of judicial deference, the Court seems instead to have recast deference as an all-purpose justification for narrowing the scope for prisoners' recovery. At times, the Court's reasoning in these cases verges on casuistry-which should trouble anyone committed to the rule of law.

\section{Limiting the Creative Use of Deference: The Court and the PLRA}

In the Court's prisoners' rights cases, deference is routinely mobilized—usually explicitly, although sometimes implicitly $7^{6}$ - to justify outcomes benefiting defendants at the expense of plaintiffs. Yet in a related body of doctrine, those cases involving the PLRA, one finds the Court eschewing the deferential strategies it freely employs in the prisoners' rights cases. This is not to say these strategies are not to be seen in the PLRA cases. One obvious example of continuity in this regard can be found in Woodford $v$. $\mathrm{Ngo,77}$ in which the Court held that failure to properly exhaust a prison's grievance procedure, whatever the circumstances, constitutes a procedural default. $7^{8}$ After Woodford, prisoners must "complete the [grievance] process in accordance with the applicable procedural rules, including deadlines, as a precondition to bringing suit in federal court."79 Ngo argued that this holding would only incentivize "prison administrators to devise procedural requirements ... designed to trap unwary prisoners and thus to defeat their claims," but the Court brushed this concern aside, asserting instead that prison officials "concerned about maintaining order ... have a reason for creating and retaining grievance systems that provide ... a meaningful opportunity for prisoners to raise meritorious grievances." $8 \circ$ For those familiar with the actual dynamics of carceral institutions, the Court's reasoning seemed very much at odds with the realities of prison life..$^{8 \mathrm{I}}$ And sure enough, in his analysis of the prison grievance procedures in several (but not all) states before and after Woodford, Derek Borchardt found that, although the grievance processes in some states had been "reasonably updated," ${ }^{82}$ in several others, grievance procedures had been revised postWoodford "in ways that cannot be understood as anything but attempts at blocking lawsuits." ${ }_{3}$

In other of the Court's PLRA cases, however, there is a refusal to endorse at least some of the deferential strategies that the Court readily adopts in its prisoners' rights jurisprudence. In Jones v. Bock, ${ }^{84}$ for example, the Court rebuffed efforts by the Sixth Circuit to impose additional procedural burdens on prisoners bringing claims..$^{85}$ Inspired by the PLRA's exhaustion requirement ${ }^{86}$-itself a statutory analogue to the deferential construction of substantive doctrine operating in cases like Turner, Whitley, and Farmer - the Sixth Circuit adopted a number of procedural rules, not present in the text of the statute, intended "to implement this exhaustion requirement and facilitate early judicial screening" of prisoner complaints. ${ }^{87}$ These rules: (I) required a prisoner wishing to file a $\int 1983$ action "to allege and demonstrate exhaustion in his complaint," (2) "permit[ted] suit only against defendants who were identified by the prisoner in his [initial] grievance," and (3) "requir[ed] courts to dismiss the entire action if the prisoner fail[ed] to [exhaust] any single claim in his complaint." ${ }^{88}$ 
As the Jones Court noted, these rules had no basis in either the PLRA-which simply states that prisoners may not bring suit in federal court "until such administrative remedies as are available are exhausted"89_or in the Federal Rules of Civil Procedure. $9^{\circ}$ For example, as to the requirement that exhaustion be demonstrated in the plaintiff's initial pleading, under the Federal Rules, exhaustion is wellunderstood to be an affirmative defense. ${ }^{9 \mathrm{I}}$ It must be invoked by defendants in their response to the complaint, ${ }^{92}$ or else be deemed to have been waived; it is thus not the job of the plaintiff to plead exhaustion in his or her initial filing. Regarding the rule that a suit may not proceed unless the named defendant was also named in the original grievance, Jones noted that it is the grievance procedures themselves, and not the PLRA, that establish the requirements of a properly filed complaint. ${ }^{93}$ And finally, as to the rule that no action may proceed unless all listed claims are exhausted, Jones pointed to the standard judicial practice that "if a complaint contains both good and bad claims, the court proceeds with the good and leaves the bad." 94

Given the absence of statutory or doctrinal support for the Sixth Circuit's additional pro-defendant procedural requirements, one might wonder how Jones could have possibly come out other than it did. In each case, the rules under scrutiny represented departures from standard practice apparently invented out of whole cloth to benefit defendants. But as has been seen, one can find in the Supreme Court's prisoners' rights cases other examples of well-established procedural rules being rewritten to bolster the position of prison officials at the expense of prisoners. 95 In Jones, however, the Court took a dim view of such an undertaking. The Court credited the Sixth Circuit with good faith in the matter, assuming its motive in imposing these rules was only to ensure that "the 'new regime' mandated by the PLRA for prisoner complaints ... function[ed] effectively." ${ }^{6}$ Yet it stated clearly that "courts should generally not depart from the usual practice under the Federal Rules on the basis of perceived policy concerns."97 Indeed, the Court admonished the Sixth Circuit that doing so would exceed the authority of the courts in the constitutional scheme, quoting Justice Frankfurter to the effect that "' $[w]$ hatever temptations the statesmanship of policy-making might wisely suggest,' the judge's job is to construe the statute-not make it better." ${ }^{8} 8$ Nor, the Jones Court emphasized, should the federal court read into a statute a congressional intent to reframe a standard judicial practice; the norm in the federal courts was that, where claims are "bad," "only the bad claims are dismissed; the complaint as a whole is not," and had Congress "meant to depart from the norm," the statute would offer some indication to this effect. 99

The Jones Court thus took the Sixth Circuit somewhat to task for doing what the Court itself did in North Carolina Prisoners' Union and in Banks. Admittedly, there are differences between Jones on the one hand and North Carolina Prisoners' Union and Banks on the other. Jones involved statutory interpretation, and the statute itself provided the
Court with a firm baseline from which to assess the Sixth Circuit's creative rule-making. By contrast, North Carolina Prisoners' Union and Banks involved constitutional claims, as to which the Court sets its own baseline. In the statutory context, it is up to Congress to weigh the various policy concerns, whereas in the universe of constitutional claims, that burden falls to the Court. But this distinction may obscure as much as it reveals. For one thing, in Banks, the Court as freely rewrote the Federal Rules as did the Sixth Circuit in Jones; after Banks, the summary judgment rules for prisoner cases are different, and more defendantfriendly, than in other cases. If this is not "depart[ing] from the usual practice under the Federal Rules on the basis of perceived policy concerns," ${ }^{\circ 0}$ it is hard to know what would be. As for the (re)description of the district court's role in evaluating evidence in prison cases in North Carolina Prisoners' Union, Justice Rehnquist did not even try to ground the change in any constitutional principles, besides that of the imperative that courts "ordinarily defer to [defendants'] judgment” in matters touching a prison's "security and order." Ior Yet as has been seen, that imperative can be readily invoked to justify any number of judicial moves - the construction of doctrine, the recasting of established procedural rules, the reframing of factual or procedural history-that benefit defendant prison officials at the expense of prisoner plaintiffs, and thus offers no principled basis for distinguishing North Carolina Prisoners' Union from Jones. ${ }^{\mathrm{IO} 2}$

And Jones is not the only PLRA case in which the Court distances itself from deferential moves it employs elsewhere in its prison law cases. The Court's PLRA jurisprudence also betrays some inclination to reject a second form of deference found throughout its prisoners' rights cases: reframing the facts in ways sympathetic to defendant prison officials. Certainly, the PLRA cases still show signs of this strategy, as the above discussion of Woodford suggests. But in Brown v. Plata ${ }^{\mathrm{IO} 3}$ - the biggest and most consequential prison case in almost two decades - the Court declined the invitation issued in Justice Alito's dissent to interpret the facts in a way that, although defendant-friendly, was stubbornly at odds with the reality of the case. In doing so, the Court showed itself able to acknowledge strategic behavior on the part of prison officials and to credit the lived experience of people in prison-capacities rarely on view in the prisoners' rights cases.

The legal question presented in Plata was whether a three-judge panel, struck pursuant to I8 U.S.C. $\int 3626$, exceeded its authority when it ordered California to reduce its prison population to 137.5 percent of the rated capacity of its facilities. ${ }^{104}$ Writing for the Court, Justice Kennedy recognized that, although the order was "of unprecedented sweep and extent," the "medical and mental health care provided by California's prisons" had "for years ... fallen short of minimal constitutional requirements" and that "[e]fforts to remedy the violation ha[d] been frustrated by severe overcrowding. ..." ${ }^{105}$ The majority opinion 
rehearsed in detail some of the many disturbing facts of the case, including that, due to "a shortage of treatment beds, suicidal inmates may be held for prolonged periods in telephone-booth sized cages without toilets"; that one such inmate, having "been held in such a cage for nearly 24 hours," was found "standing in a pool of his own urine, unresponsive and nearly catatonic" because prison officials had "no place to put him"; ;o6 and that due to lack of space, "up to 50 sick inmates may be held together in a I2-by 20-foot cage for up to five hours awaiting treatment." ${ }^{\text {I07 }}$ Justice Kennedy then, as Linda Greenhouse aptly put it, "plowed methodically through every section of the [PLRA]" and agreed with the panel's conclusion as to each. ${ }^{108}$

Noting that the Court's stance was "necessarily deferential" as to the panel's findings of fact, the majority opinion canvassed some of the evidence heard at trial and found it to support the conclusion that crowding was, as required by $\int_{3} \sigma_{2} 6$, the "primary cause" of the constitutional violation. ${ }^{\text {I09 }}$ It also endorsed the panel's finding that "no other relief" would remedy the violation, agreeing that although alternatives existed in theory, there was "no realistic possibility that California would be able to build itself out of the crisis" and that any remedy requiring "significant additional spending by the state" was "chimerical." Iо As Justice Kennedy put it, "The Court cannot ignore the political and fiscal reality behind this case": the state legislature had been unable or unwilling "to allocate the resources necessary to meet this crisis" and "[t]here is no reason to believe it will begin to do so now," when it faces "an unprecedented budgetary shortfall." III Finally, the Court found that the panel had given "substantial weight" to public safety, ${ }^{\mathrm{II} 2}$ noting the considerable statistical and other testimony evidence heard at trial indicating that the order "would have little or no impact on public safety." I3 Defending the panel's conclusion as sufficiently supported, the Court observed that the PLRA "does not require the court to certify that its order has no possible adverse impact," since such a reading "would depart from the statute's text by replacing the word 'substantial' with "conclusive." II

In sum, the three-judge panel in Plata had systematically analyzed its own proposed remedial order in light of statutory requirements, and the Supreme Court, reviewing that analysis in light of the facts and procedural history, agreed that the panel had met the strict burdens of $₫ 3626$, and thus upheld the order. Acknowledging the deference it owed to the panel's findings of fact, the Court credited the panel's account of the evidence and echoed the realism that attended the panel's deliberations as well as its reluctance to allow defendants' implausible assertions to derail statutorily authorized remediation.

Ordinarily there would be nothing surprising here; appellate courts undertake this sort of review all the time. But for a prison law case, Plata's majority opinion was notable for what it did not do, i.e., avail itself of any of the deferential moves that more typically inform the Court's rulings in this area. It did not, for example, rewrite the rules of appellate review, but forthrightly acknowledged that " $[w]$ ith respect to the three-judge court's factual findings, this Court's review is necessarily deferential." "I5 In assessing the panel's conclusion that overcrowding was the "primary cause" of the violation —as it needed to be if the panel's order was to satisfy $₫ 3626$ - the Court even passed up a chance to justify de novo review: although it noted that the "issue of primary cause presents a mixed question of law and fact," it found that in this case "the mix weighs heavily on the fact side."

It was left to Justice Alito in dissent to advocate the recasting of rules governing appellate review. Although it is standard practice for trial courts to assess expert testimony as part of its fact-finding role, Justice Alito insisted that, given the issue presented, the weighing of expert evidence in this case was of a different order. As he put it, when a trial court considers expert testimony "on broad empirical questions such as the efficacy of preventing crime through the incapacitation of convicted criminals," its "choice is very different from a classic finding of fact and is not entitled to the same degree of deference on appeal." II7 Justice Alito offered no justification for this departure from the standard rules of appellate review beyond this recitation of the substantive issue; indeed, he seemed not even to realize such a justification was warranted. Perhaps more revealing still, Justice Alito's dissent made clear that no amount of evidence could convince him that the panel had satisfied its obligation under $\int 3626($ a) (I) to "give substantial weight to any adverse impact on public safety." ${ }^{\text {II } 8}$ In taking this position, Justice Alito thus indicated not only that he would have departed from accepted standards for appellate review, but also that he would have effectively negated even the limited statutory protection of $\llbracket 36_{2} 6$ in a case involving the largest imaginable affected class.

But Justice Kennedy's opinion in Plata is particularly notable for its eschewal of the third form deference can take in prison law cases, a stance evident in its willingness to take the record at face value and accept the facts as given without seeking to reframe them in defendantfriendly ways. Again, it was left to Justice Alito in dissent to present the facts in ways inconsistent with the record, which he did most obviously in his discussion of the PLRA's narrow tailoring requirement. ${ }^{119}$ The three-judge panel had found that without reducing prison overcrowding, the state would be unable to ensure the constitutionality of its medical and mental health care. It based this finding on California's years of noncompliance with seventy-plus judicial orders issued in the two cases. ${ }^{120}$ As the panel explained, it was not that the defendants were unaware of what reforms were needed, but that the state had plainly demonstrated over two decades its inability to effect them. ${ }^{\text {I2I }}$

Justice Alito's discussion brushed this history aside. Instead, it focused narrowly on what it would take to remedy the "deficiencies" in the prison's medical and mental health care delivery systems ${ }^{\mathrm{I} 22}$ and reads as if its proposed 
solutions had simply escaped judicial notice. According to Justice Alito:

Many of the problems [identified by the Court] could be addressed without releasing prisoners and without incurring the costs associated with a large-scale prison construction program. Sanitary procedures could be improved; sufficient supplies of medicine and medical equipment could be purchased; an adequate system of records management could be implemented; and the number of medical and other staff positions could be increased. Similarly, it is hard to believe that staffing vacancies cannot be reduced or eliminated and that the qualifications of medical personnel cannot be improved by any means short of a massive prisoner release. ${ }^{123}$

Justice Alito thus concluded that "[w]ithout specific findings backed by hard evidence, this Court should not accept the counterintuitive proposition that these problems cannot be ameliorated by increasing salaries, improving working conditions, and providing better training and monitoring of performance." ${ }^{124}$ In the context of this case, however, this reasoning is wholly at odds with the facts. Taken together, the histories of Plata and Coleman (the two consolidated cases at issue) featured over two decades of the state's inability to implement the particular changes-including those listed by Justice Alito- that all parties agreed were necessary to ensure constitutional levels of care. The panel issued its order after years of working with the state to try to bring about constitutional compliance, finally concluding that no progress could be expected absent a reduction in crowding. Yet Justice Alito wrote as if the panel's order was its first resort, and as if the decades of failed efforts at compliance had never occurred.

Thus, in Plata, at least two forms of deference typical of prisoners' rights cases were on view in Justice Alito's dissent, while the majority eschewed them both in favor of a systematic and even-handed analysis of the questions presented. Perhaps too much should not be made of this departure from the Court's usual treatment of prison law issues; the case was so massive and the conditions so extreme that there is unlikely ever to be another like it. Still, it seems noteworthy that the two cases in which the Court most obviously abstained from using the deferential moves it employs elsewhere in the prison law context are PLRA cases. With the passage of the PLRA, Congress enacted a set of rules to govern prisoners' rights cases that, as with the standards established in Turner, Farmer, and Whitley, directly manifest the imperative of judicial deference to prison officials. ${ }^{22}$ Some of these same provisions, moreover, impose additional procedural burdens on prisoners bringing \I983 actions, creating exceptions to established rules for the prisoners' rights context much like the Court did in North Carolina Prisoners' Union and Banks. ${ }^{126}$ It may only be a coincidence that Jones and Plata are both PLRA cases. But it is also possible that even a Court ordinarily inclined to adopt deliberative strategies sympathetic to defendant prison officials may hesitate to do so in cases where the applicable law already features both highly deferential substantive standards and a host of procedural rules rewritten to be more onerous for prisoners than for other $\llbracket$ I983 plaintiffs. Given the burdens the PLRA imposes on prisoner suits, defendants in the PLRA cases that make it to the Supreme Court will already have enjoyed the benefit of multiple forms of deference. ${ }^{127}$ Perhaps even in the prison law context there may be an implicit upper limit to how much deference to defendant prison officials the Court is willing to allow.

Of course, any such account must allow for possible variation among the Justices. Justice Scalia, for one, implies in his Plata dissent that at least in some cases, there are no limits to his determination to find a way to rule against prisoners. Not one to mince words, Justice Scalia dismissed the panel's proceedings as "a judicial travesty" and its order as "absurd." ${ }^{28} 8$ Lest one think this assessment was based on considered analysis of the facts in light of the relevant PLRA provisions, Justice Scalia made clear that for his part, even had the order satisfied the PLRA's requirements to the letter, it would not have been enough for him. As he put it, "[o] ne would think that, before allowing the decree of a federal district court to release 46,000 convicted felons"-a misstatement of the order, ${ }^{\mathrm{I} 29}$ it bears noting - "this Court would bend every effort to read the law in such a way as to avoid that outrageous result." 130

This language reinforces the strong impression that a canvassing of the Court's prison law cases already creates-that rather than applying the relevant law in good faith to the facts of cases involving prisoners, at least some Justices will "bend every effort to read the law" to favor the defendants at the expense of the plaintiffs. ${ }^{\mathrm{I3I}}$ And for those inclined to such manipulation, the doctrine has featured a ready mechanism: the imperative of judicial deference, which in the absence of established principles for its application has proved sufficiently flexible to allow the impression of good faith legal reasoning while stacking the deck in defendants' favor. It is perhaps this flexibility, afforded by the absence of any principled account to guide (and constrain) the invocation of deference in the prison context, that offers the strongest evidence of the need for such an account.

\section{Towards a Principled Theory of Deference}

Even in prisoners' rights cases, the Court does not always find for defendants. In Cleavinger v. Saxner, ${ }^{\mathrm{I} 2}$ for example, prison officials sought absolute immunity from suit for actions taken in their capacity as hearing officers in prison disciplinary matters. ${ }^{133}$ The Court, however, rebuffed these efforts. Recognizing the pressures hearing officers feel to credit the testimony of fellow officers against that of inmates, ${ }^{134}$ the Court rejected defendants' claim that "ample safeguards" existed to protect the due process rights of prisoners at disciplinary hearings. ${ }^{135}$ It thus concluded that only qualified immunity and not absolute 
immunity was appropriate. ${ }^{136}$ And in Turner v. Safley, the Court struck down a Missouri regulation prohibiting prisoners from marrying without the approval of the superintendent ${ }^{\mathrm{t} 37}$ after it scrutinized the justifications offered in defense of the rule and found them illogical. ${ }^{138}$

Nor is the Court's invocation of deference in prison law cases always misplaced. In Lewis v. Casey, ${ }^{139}$ for example, Justice Scalia was right to chastise the district court for imposing a minutely detailed order for the revamping of the Arizona prisons' law libraries that had been crafted without consulting the state. ${ }^{140}$ As Justice Scalia observed, the better approach would have been to "charge[] the Department of Correction with the task of devising a Constitutionally sound program," thereby "permitting prison administrators to exercise wide discretion within the bounds of constitutional requirements" ${ }^{\text {I4I }}$ —an approach, it bears noting, to which the Plata and Coleman courts scrupulously adhered throughout the history of both those cases.

The problem in the prisoners' rights cases, and in the prison law cases more generally, is thus not the use of deference per se, but the lack of any guiding principles for its application. As a body, the prisoners' rights cases currently stand for the implicit proposition that a greater measure of deference is warranted when the plaintiffs are prisoners, but to date, support for this position has been more assertion than argument. Indeed, given the profound, real-life consequences of its prison law cases, it is telling how little effort the Court has expended to justify in a meaningful way its readiness to defer. Instead, its defense of deference in the prison context has most often rested on the contents of one oft-repeated paragraph, first appearing in the reform era case $\mathrm{I}^{\mathrm{I} 2}$ of Procunier v. Marti$n e z,{ }^{\text {I43 }}$ in which the Court referred to the "Herculean obstacles" prison officials face to the "effective discharge of [their] duties," and described "the problems of prisons in America" as "complex and intractable" and "not readily susceptible of resolution by [judicial] decree." I44 The Court thus concluded that "courts are ill equipped to deal with the increasingly urgent problems of prison administration and reform." "45 Perhaps nothing so plainly indicates the absence of efforts by the Court to defend its inclination to defer in this context than the subsequent career of this paragraph, which has been deployed to justify a deferential stance in the Court's prison law cases at least fourteen times since Martinez was decided. ${ }^{\mathrm{I} 6}$

If the Court's prison law jurisprudence is to be legitimate, a theory of judicial deference for the prison law context is required, to address the questions of when deference is justified, what forms it may legitimately take, which aspects of a court's deliberations it may appropriately influence, and the proper limits on its use. The present survey suggests that a focus on the prison law cases would be a worthwhile place to begin crafting such a theory. Relevant questions would include whether deference in practice takes any forms beyond those I have identified (and indeed whether what I have described as forms of deference are accurately characterized as such); whether the cases suggest any patterns as to when and in what forms deference is invoked; and whether those patterns reveal any principled bases for that invocation. As to this last, Jones and Plata would be a fruitful starting point, since in these cases, with little fanfare, the Court forbore from deploying the deferential strategies so often seen in the prisoners' rights cases in particular. In Part II above, I offered a theory as to why this might be: in light of the extremely pro-defendant cast of the PLRA, at least some Justices may resist taking still further steps to benefit prison officials. Whether this theory is ultimately compelling and what it might offer in terms of principled limits on the employment of additional pro-defendant deferential strategies in general are questions meriting further consideration.

At the same time, efforts to develop a principled account of judicial deference for the prison law context should also reach beyond the cases, to consider at a more abstract level when, if ever, it is appropriate for courts to make the kinds of moves routinely seen in the Court's prisoners' rights jurisprudence. Doing so will require grappling directly with the various institutional concerns that might explain the Court's determination to defer in this context. These concerns, all of which feature in that oft-cited Martinez paragraph, have been staples of the federal courts' prison law cases for over a century. ${ }^{\mathrm{I} 47}$ Most prominent among them is the notion of relative institutional competency, i.e., the view that prison officials and not the courts have the expertise necessary to deal with the "complex and intractable" problems of American prisons. ${ }^{148}$ But they also include more general concerns with the demands of federalism ${ }^{\mathrm{I} 49}$ and separation of powers, ${ }^{\mathrm{I}}{ }^{50}$ as well as with the possibility of inviting a deluge of frivolous prisoner complaints. ${ }^{\mathrm{I} I}$

These are just the sorts of institutional concerns that, as Lawrence Sager famously observed, may keep the federal courts from enforcing constitutional norms "to their full conceptual limits." "I52 Sager argued that "when the federal courts restrain themselves for reasons of competence and institutional propriety ..., it is incongruous to treat the products of such restraint as authoritative determinations of constitutional substance" 553 -in other words, that a court's decision for institutional reasons to narrow the scope of constitutional protections should not be mistaken for a decision on substantive constitutional grounds. Applied to the prison context, Sager's point can be read as an admonition to prison officials that, even if a federal court declines to fully enforce prisoners' constitutional rights, the state is still constitutionally bound to honor those rights in a meaningful way. However, without principles justifying the nature and scope of judicial deference to prison officials, it is impossible to determine whether courts have properly forborne from more capacious enforcement of prisoners' constitutional rights. And following Sager's logic, to the extent that the deference currently shown to prison officials proves on reflection to be excessive, there may well be grounds for thinking that 
courts too have been failing to live up to the full measure of their constitutional obligations.

The legal field I have been calling "prison law" is actually an amalgam of several areas of law, chief among them administrative law and constitutional law. Issues of judicial deference-or "levels of scrutiny" in the constitutional context-are central to both these areas, and any inquiry into appropriate deference for the prison law context may thus also need to consider, and likely wrestle with, the tensions in both administrative law and constitutional law between judicial power on the one hand and executive and legislative power on the other. Of the two, administrative law in general seems particularly relevant to an inquiry into appropriate limits on deference. Prisons are run by government agencies, albeit agencies with special status in the administrative law universe. ${ }^{54}$ Much of the doctrine in the administrative law arena is concerned with the appropriate scope of judicial deference to agency determinations. ${ }^{155} \mathrm{~A}$ set of questions thus naturally arises: In what ways does or should deference in the prison law context differ from deference granted to other administrative agencies? Ought prisons to be treated the same as other agencies? To what extent should the answer depend on the nature of the challenged regulation or practice? On the process by which it was established? ${ }^{156}$ As for constitutional law, the scholarly literature affords a rich discussion regarding the various levels of scrutiny courts will bring to bear on constitutional claims. ${ }^{157}$ In the prisoners' rights context, there is an obvious tension between the Turner test, which if not identical to rational basis review is certainly a species of it, and the fact that in many cases, it is prisoners' fundamental rights—ordinarily afforded heightened scrutiny — that are at issue. Consideration of the ways that constitutional law scholars, and the Justices themselves, understand and justify the existing scheme of judicial scrutiny may thus prove useful to crafting a principled approach to deference in the prison context. ${ }^{158}$

This way of approaching the issue assumes that deference in the prison context may be understood at least to some extent as a species of a general, cross-doctrinal legal concept. To some readers, however, this notion may seem to give the Court too much credit. Given its minimal efforts to justify the extent to which it defers to prison officials, and given that at least two forms that deference takes in this context- the refashioning of procedural rules to disadvantage prisoners, and a persistent readiness to interpret the facts to favor defendants-seem at least on the surface of questionable legitimacy, and given the Court's generally evident determination to find ways to allow defendant prison officials to prevail, one might instead regard the Court's repeated invocation in its prison law cases of the need to defer as just a makeweight: a convenient, authoritative-seeming basis on which to ensure that the prisoners almost always lose. Seen in this light, it is misguided to think that the Court's use of "deference" in other contexts will shed light on the use of this notion in the prison context; although the term is found elsewhere, there in practice is no meaningful commonality.

There may be something to this skeptical view. Certainly, on the surface, there seems scant resemblance between, for example, the kinds of burdens the court imposes on administrative agencies before it will defer to their expertise in the crafting of regulations pursuant to their statutory authority and the broad grants of discretion to prison officials embodied in the prisoners' rights doctrine. ${ }^{159}$ It is, moreover, hard to square the Court's heightened scrutiny in cases involving fundamental constitutional rights in general with the extremely limited review accorded the policies and practices burdening the fundamental constitutional rights of prisoners.

Yet the fact that a trans-substantive investigation into the forms of judicial deference is likely to reveal the prison law context as an outlier and even as a site of systematic judicial bias against a particular plaintiff class does not diminish the potential value of the enterprise. To the contrary, exposing dissimilarity in the way judicial deference is used in other doctrinal contexts as compared with its use in the prison law cases would only reinforce the need for a principled account of deference in the prison context. Such a comparative exercise, moreover, is sure to provide potentially useful guidance for the crafting of such an account, drawn from instances in which the Court more aggressively exercises its obligations of constitutional enforcement and judicial review.

At the same time, moreover, efforts to make sense of the use of judicial deference in the specific context of prisons may also prove fruitful in the other direction, yielding insights of broader doctrinal relevance. For example, exploring the possibility that the Court's prison law jurisprudence is informed by an implicit animus toward the affected class will invite engagement with the more overtly normative issues raised in Carolene Products' famous footnote four, ${ }^{160}$ including whether and to what extent the political status of plaintiffs in general may justifiably influence judicial deliberations. ${ }^{16 \mathrm{I}}$ And examining the forms deference takes in the prison context may also offer a typology with general application. In addition to those forms of deference explored in Parts I and II, the prison law cases also reveal a further, more subtle dimension of judicial scrutiny that doubtless has analogues in many other areas: the degree to which, as a deliberative matteror perhaps as a matter of judicial psychology—courts are willing to press on the strength of defendants' arguments. ${ }^{162}$ As was seen in Part I, the prison law cases are full of examples in which the Court endorses the defendants' version of the facts even when strong evidence contradicts it, and accepts the defendants' claimed justifications for the challenged policy or practice even in cases where minimal pressure on the proffered reasoning would reveal its illogic. In some cases-for example, North Carolina Prisoners' Union-the Court is explicit about its obligation to accept defendants' claims absent "substantial evidence ... that the officials have exaggerated their 
response." ${ }^{163}$ In other cases-for example, Whitley $v$. Albers - the Court adopts without explanation the defendants' version of the facts, even when evidence in the record strongly contradicts their version and the procedural posture demands viewing the evidence in the light most favorable to the plaintiffs. ${ }^{164}$ Either way, as Justice Stevens trenchantly observed in his opinion in Turner, "[h]ow a court describes its standard of review when a prison regulation infringes fundamental constitutional rights often has far less consequence for the inmates then the actual showing that the court demands of the State in order to uphold the regulation." ${ }^{165}$ Efforts to develop a principled account of judicial deference in the prison law context may thus also prompt consideration of the way this less tangible but no less significant form of judicial scrutiny operates elsewhere.

The quest for a defensible account of judicial deference in the prison law context invites analysis on multiple dimensions: doctrinal, institutional, comparative, normative, and even psychological. All told, given the complexity of the carceral enterprise, judicial deference to prison officials may well be more readily justified than judicial deference in other contexts. But even so, there remains an urgent need for clearly articulated principles, since absent a principled basis for deploying deference, the law governing prisons and prisoners cannot be regarded as legitimate by those it most affects-nor, arguably, does it deserve to be.

\section{Notes}

1 I thank Rachel Barkow, Jody Freeman, Giovanna Shay, and especially Dick Fallon for helpful comments and conversation, and Erin Earl for outstanding research assistance.

2 See Cooper v. Pate, 378 U.S. 546 (1964) (holding for the first time that state prisoners can sue in federal court under $\S 1983$ for violation of their constitutional rights); see also Wolff v. McDonnell, 418 U.S. 539, 555-56 (1974) ("There is no iron curtain drawn between the Constitution and the prisons of this country.").

3 For example, Procunier v. Martinez, 416 U.S. 396 (1974), decided at the height of what is widely regarded as the "reform" era of prisoners' rights litigation, see MALCOLM M Feeley \& EdWARD L. Rubin, Judicial Policy Making and the Mod ERN STATE 39 (1998), plainly demonstrates this ambivalence. Although Martinez was decided in favor of the prisoners, 416 U.S. at 398, Justice Powell took pains to emphasize that prison officials face "Herculean obstacles to effective discharge of [their] duties," id. at 414, and that "courts are ill equipped to deal with the increasingly urgent problems of prison administration and reform," id. at 405. And if Martinez still went on to insist that "a policy of judicial restraint can. not encompass any failure to take cognizance of valid constitutional claims," id., it was its emphasis on the judicial obligation to defer that proved to be the lasting legacy of the case. While Martinez's key doctrinal move-emphasizing that restricting prisoners' First Amendment rights also restricts the First Amendment rights of free people, thereby justifying heightened scrutiny of restrictions on prisoners' freedom of expression-did not even last the Term, see Pell v. Procunier, 417 U.S. 817 (1974) (upholding a prohibition on media access to particular prisoners without even noting the First Amendment interest of the reporters involved when analyzing the prisoners' First Amendment claim), Justice Powell's language in Martinez emphasizing the need for judicial defer ence has been quoted frequently in subsequent cases to justify finding for prison officials. For further discussion of the lasting influence of this language from Martinez, see infra Part III and note 146.

4 See Sharon Dolovich, Cruelty, Prison Conditions, and the Eighth Amendment, 84 N.Y.U. L. REv. 881, 961-62 \& n.306 (2009) (describing the role of deference in the history of prisoners' rights litigation).

5 Pub. L. No. 104-134, §§ 801-810, 110 Stat. 1321-66 (1996) (codified in scattered sections of $11,18,28$, and 42 U.S.C.).

6549 U.S. 199 (2007)

$7 \quad 131$ S. Ct. 1910 (2011).

8 The cases in this essay involve civil rights claims brought under 42 U.S.C. $\S 1983$ and Bivens v. Six Unknown Named Agents of Federal Bureau of Narcotics, 403 U.S. 388 (1971). Thus, references to "defendants" throughout refer to the state prison officials sued by prisoner-plaintiffs for constitutional violations.

9 Lewis v. Casey, 518 U.S. 343, 361 (1996).

10482 U.S. 78 (1987).

11 ld. at 89.

12 Id. (quoting Block v. Rutherford, 468 U.S. 576, 586 (1984)).

13 Id. at 90.

14 ld.

15 Id.

16 Id. at $89-90$

17 Id. at 90 (citation omitted) (quoting Jones v. N.C. Prisoners' Labor Union, Inc., 433 U.S. 119, 131 (1977); Pell v. Procu. nier, 417 U.S. 817, 827 (1974)) (internal quotation marks omitted). In Overton v. Bazzetta, the Court went further, say. ing that alternatives "need not be ideal," but "need only be available." 539 U.S. 126, 135 (2003).

18 Turner, 482 U.S. at 90

19 Id. at 91.

20 See Columbia Human Rights Review, A Jailhouse Lawyer's MANUAL 377 (9th ed. 2011), available at http://www3.law. columbia.edu/hrlr/jlm/toc/ ("In most cases, a prison regu lation survives the Turner test because it only requires that the government's explanation for the regulation be rational (that it makes sense). This is not a very high standard for the government to meet."); Margo Schlanger, Inmate Litigation, 116 HARV. L. REV. 1555, 1605-07 \& n.139 (2003) (examining the results of an empirical study of inmate cases and explaining that "inmates are only very rarely suc. cessful in their federal civil rights actions," id. at 1605, in part because of "extremely defendant-friendly standards," including Turner, id. at 1605 n.139). And even when a pris. oner-plaintiff does prevail on a Turner analysis, the victory is frequently short-lived. See, e.g., Overton v. Bazzetta, 286 F.3d 311, 316-18, 323-24 (6th Cir. 2002) (holding on Turner grounds that Michigan's restrictions on visitations violated prisoners' constitutional rights), rev'd, 539 U.S. 126 (2003); Gerber v. Hickman, 264 F.3d 882, 887-90 (9th Cir. 2001) (holding on Turner grounds that plaintiff's constitutional rights were violated by defendants' refusal to allow him to arrange for the transport outside the prison of his own semen, which he (and his wife) wished for his wife to use for purposes of artificial insemination), rev'd, 291 F.3d 617 (9th Cir. 2002) (en banc).

21475 U.S. 312 (1986)

22 E.g., Estelle v. Gamble, 429 U.S. 97, 104 (1976); see also Wil. son v. Seiter, 501 U.S. 294, 303 (1991).

23 Whitley, 475 U.S. at 320-21 (quoting Johnson v. Glick, 481 F.2d 1028, 1033 (2d Cir. 1973) (Friendly, J.)) (internal quota. tion mark omitted). The Whitley standard initially applied only to the use of force in a "disturbance." Id. But in Hudson v. McMillian, the Court extended Whitley to all use of force 
claims, whether arising from a "disturbance" or not. See 503 U.S. 1, 7 (1992).

24511 U.S. 825 (1994).

25 See id. at 838 ("[A]n official's failure to alleviate a significant risk that he should have perceived but did not, while no cause for commendation, cannot . . . be condemned as the infliction of punishment.").

26501 U.S. 294 (1991)

27 Id. at 300

28 See Dolovich, supra note 4, at 895-907 (arguing this view in detail).

29433 U.S. 119 (1977)

30 See id. at 122-23.

31 N.C. Prisoners' Labor Union, Inc. v. Jones, 409 F. Supp. 937, 942 (E.D.N.C. 1976)

32 Id. at 943

33 Id. at 944

$34 \mathrm{ld}$.

35 Id.

36 Jones v. N.C. Prisoners' Labor Union, Inc., 433 U.S. 119, 121 (1977).

37 Id. at 126

38 Id. at 127-28 (emphasis added) (citations omitted) (internal quotation marks omitted).

39 See also id. at 132 ("Appellant prison officials concluded that the presence, perhaps even the objectives, of a prisoners' labor union would be detrimental to order and security in the pris. ons. It is enough to say that they have not been conclusively shown to be wrong in this view." (internal citations omitted)).

40 N.C. Prisoners' Labor Union, 409 F. Supp. at 943.

41548 U.S. 521 (2006).

42 Id. at 527-28, 536 (plurality opinion).

43 Id. at 529 (quoting Turner v. Safley, 482 U.S. 76, 89 (1987)) (internal quotation marks omitted); id. at 531.

44 ld. at 530 .

45 Id. at 531 (alteration in original) (internal quotation mark omitted).

46 See id. at 534

47 ld.

48 Id. at 535 (quoting Banks v. Beard, 399 F.3d 134, 142 (3d Cir. 2005)) (internal quotation marks omitted).

49 Id. at 543-52 (Stevens, J., dissenting).

50 FED. R. CIV. P. 56(a).

51 Banks, 548 U.S. at 535 (plurality opinion). In his concurrence, Justice Thomas, joined by Justice Scalia, reaffirmed his position that prisoners have no constitutional rights apart from the Eighth Amendment. See id. at 537 (Thomas, J., concurring). There were thus arguably six votes supporting the Banks plurality's more restrictive summary judgment stan. dard for cases brought by prisoners.

52 Masson v. New Yorker Magazine, Inc., 501 U.S. 496, 520 (1991).

53 Banks, 548 U.S. at 530 (plurality opinion) (emphasis added).

54 ld.

55 Id. at 554 (Ginsburg, J., dissenting)

56 Id. at 556 (emphasis in original).

57 Id. As Justice Ginsburg put it, "the plurality effectively tells prison officials they will succeed in cases of this order, and swiftly, while barely trying." Id.

58452 U.S. 337 (1981)

59 Id. at $346,348$.

60 ld. at 348

61 Id. at 371 \& n.3 (Marshall, J., dissenting).

62 See 475 U.S. 312, 317-18 (1986).

63 Id. at 322-23.

64 Id. at 330 (Marshall, J., dissenting); see also id. at 331 ("Although the Court sees fit to emphasize repeatedly 'the risks to the life of the hostage and the safety of inmates....,
I can only point out that respondent bitterly disputed that any such risk to guards or inmates had persisted. The Court just does not believe his story." (internal citation omitted)).

65539 U.S. 126 (2003).

66 Id. at 135.

67 ld.

68518 U.S. 343 (1996)

69430 U.S. 817 (1977).

70 ld. at 828

71 Casey, 518 U.S. at 354 (citation omitted).

72 Id. at 354.

73 Bounds, 430 U.S. at 825.

74 ld. at 826 .

75 Of course, depriving prisoners of outside visits, one of the few bright spots in an otherwise dispiriting existence, may well simply push those prisoners inclined to drugs or alcohol to use these substances as a way to dull their pain.

76 In almost all the cases discussed above, the Court justifies the moves it makes by explicit reference to the need to defer. See infra note 146 \& accompanying text; see also Beard v. Banks, 548 U.S. 521, 530 (2006) (plurality opinion) (justify. ing the change in the summary judgment standard as applied to prisoners by the Court's obligation to defer to prison officials on "matters of professional judgment"); Whitley v. Albers, 475 U.S. 312, 321-22 (1986) (citing language in Rhodes v. Chapman, 452 U.S. 337, 349 (1981), and Bell v. Wolfish, 441 U.S. 520, 547 (1979), regarding the need for judicial deference to prison officials). In cases where it does not, the imperative to defer is generally already embodied in the substantive standards being applied-as in Overton v. Bazzetta, 539 U.S. 126 (2003), which applied the Turner stan. dard to regulations restricting plaintiffs' visiting privileges. The one exception is Farmer v. Brennan, 511 U.S. 825 (1994), which does not explicitly invoke the need to defer in crafting the standards for Eighth Amendment prison conditions claims. In that case, however, it is hard to understand either the Court's holding or the justifications offered for it as any. thing other than the determination to create a zone for official action in which prison officials can exercise discretion without fear of constitutional liability. For further discussion of the deferential character of the Farmer standard, see Dolovich, supra note 4, at 895-907, 940-72.

77548 U.S. 81 (2006).

78 ld. at 87

79 Id. at 88

80 ld. at 102

81 See Margo Schlanger \& Giovanna Shay, Preserving the Rule of Law in America's Jails and Prisons: The Case for Amending the Prison Litigation Reform Act, 11 U. PA. J. CoNST. L. 139, 149-50 (2008) ("[T] he PLRA's exhaustion rule actually provides an incentive to [prison and jail] administrators . . . to fashion ever higher procedural hurdles in their grievance processes. ... Can anyone reasonably expect a governmental agency to resist this kind of incentive to avoid merits consideration of grievances?").

82 Derek Borchardt, Note, The Iron Curtain Redrawn Between Prisoners and the Constitution, 43 Colum. Hum. RTS. L. Rev. (forthcoming 2012) (manuscript at 58-59) (on file with author) (listing Connecticut, Hawaii, Idaho, Indiana, and Mississippi as states with grievance procedures that seemed "reasonably updated" after Woodford). But see id. (manuscript at 29) (noting that because his research relied on states being willing to share the details of their grievance proce. dures, "it is possible that the states that treat their grievance procedures the most mischievously escaped scrutiny in this Note, while more reasonable states received criticism due to their willingness to make documents available").

83 Id. (manuscript at 5); see id. (manuscript at 32-58) (listing Alabama, Arizona, Arkansas, Colorado, Delaware, and 
Oklahoma as states that either provide no guidance at all for prisoners wishing to file grievances or that have revised their requirements in ways "impossible to understand... as anything but "procedural requirements that are designed to trap unwary prisoners and ... to defeat their claims,'" id. (manuscript at 46) (second alteration in original) (quoting Woodford, 548 U.S. at 102))

Among other strategies adopted post-Woodford, state Departments of Correction reduced from ten days to five the length of time available for filing or appealing a grievance (Arizona), id. (manuscript at 37); revised the rules to require that the initial grievance "specifically name" the personnel involved, thereby justifying dismissal at later stages if the grieving inmate initially misidentified or omitted the names of responsible officials (Arkansas), id. (manuscript at 42-44); revised the grievance forms to omit description of procedural requirements (Arkansas again), id. (manuscript at 48); mandated that the grievance process shall be deemed not to have been exhausted if a filed grievance is found to be "incom. plete, inconsistent with a former step, incomprehensible, illegible ... fails to request relief," or "in any other way fails to comply with" the grievance procedure (Colorado), (manu script at 50-51); added additional steps to the grievance process (Oklahoma), id. (manuscript at 55-57); and changed the rules to require dismissal of the grievance if the inmate alters the grievance forms or "attach[es] additional documents to the formal grievance, other than the requisite forms" (Oklahoma), id. (manuscript at 57).

84549 U.S. 199 (2006).

85 Id. at 202-03.

8642 U.S.C. § $1997 \mathrm{e}(\mathrm{a})(2006)$

87 Jones, 549 U.S. at 202-03.

88 ld. at 203.

8942 U.S.C. $\S 1997 e(a)$

90 See Jones, 549 U.S. at 212.

91 Id.

92 See Fed. R. CIV. P. 8(c); Jones, 549 U.S. at 212-17.

93 See Jones, 549 U.S. at 218.

94 Id. at 221.

95 See supra Part I (discussing Jones v. N.C. Prisoners' Union and Beard v. Banks).

96 Jones, 549 U.S. at 213.

97 Id. at 212.

98 Id. at 216 (quoting Felix Frankfurter, Some Reflections on the Reading of Statutes, 47 Colum. L. Rev. 527, 533 (1947)).

99 Id. at 221 (quoting Robinson v. Page, 170 F.3d 747, 748-49 (7th Cir. 1999)) (alteration and internal quotation mark omitted).

$100 / d$. at 212.

101 Jones v. N. C. Prisoners' Union, Inc., 433 U.S. 119, 128 (1977).

102 Comparing Jones with North Carolina Prisoners' Union and Banks makes clear the need for principled limits on the deployment of deference in the prison law context in general, whether the cases are statutory or constitutional. As Jones itself intimated, if the system is to maintain its legitimacy, these limits must be crafted with more than just policy preferences in mind.

103131 S. Ct. 1910 (2011).

104 ld. at $1922-23$

105 Id. at 1923.

106 Id. at 1924

107 Id. at 1925

108 Linda Greenhouse, A Voice from the Past, N.Y. TIMES OPINION. ATOR (June 1, 2011 9:00 PM), http://opinionator.blogs. nytimes.com/2011/06/01/a-voice-from-the-past/.

109 Plata, 131 S. Ct. at $1932-34$

110 /d. at 1938 (internal quotation marks omitted)

111 Id. at 1939. As the Court noted, "[T]he common thread con. necting the State's proposed remedial efforts is that they would require the State to expend large amounts of money absent a reduction in overcrowding." Id.

112 Id. at 1941.

113 /d. at 1943.

114 Id. at 1941

115 ld. at 1932.

116 Id. (quoting Lilly v. Virginia, 527 U.S. 116, 148 (1999) (Rehnquist, C.J., concurring in the judgment)) (internal quo. tation marks omitted)

117 Id. at 1966 (Alito, J., dissenting).

118 See id. at 1965-67 (discussing a court's obligation under the PLRA to "give substantial weight to any adverse impact on public safety or the operation of a criminal justice system caused by the relief," id. at 1965 (quoting 18 U.S.C. $\S 3626(a)(1)(A)(2006))$.

119 Under the PLRA, federal courts may only issue remedial orders in prison conditions cases if that relief "is narrowly drawn, extends no further than necessary to correct the viola tion of the Federal right, and is the least intrusive means necessary to correct the violation," and if in crafting that relief, the court "give[s] substantial weight to any adverse impact on public safety ...." 18 U.S.C. § 3626(a)(1)(A).

120 Plata, 131 S. Ct. at 1930-31.

121 See Coleman v. Schwarzenegger, No. CIV S-90-0520 LKK JFM P, at 102-14 (E.D. Cal. Aug. 8, 2009)

122 Plata, 131 S. Ct. at 1963 (Alito, J., dissenting) (noting, among other deficiencies identified by the panel, exam tables and counters "not routinely disinfected," medical facilities "in an abysmal state of repair," necessary medica. tions and medical equipment "unavailable," low hiring standards and "high vacancy rates" (internal citations and quotation marks omitted)).

123 Id. at 1964

124 ld.

125 See, e.g., 18 U.S.C. § 3626(e)(2) (2006) (requiring that "any motion to modify or terminate" a consent decree regarding prison conditions be treated as an "[a]utomatic stay"); 42 U.S.C. $\S 1997 \mathrm{e}(\mathrm{e})$ (2006) (stipulating that no prisoner can bring a claim for "mental or emotional injury suffered while in custody without a prior showing of physical injury").

126 See, e.g., 28 U.S.C. § 1915(b)(1) (2006) (stipulating that, although in the ordinary case, people who affirm that they are indigent may file a complaint without paying the filing fee, see 28 U.S.C. § 1915(a)(1), a prisoner who "brings a civi action or files an appeal in forma pauperis ... shall be required to pay the full amount of a filing fee," albeit over time); 28 U.S.C. $\S 1915$ (g) (stipulating that any prisoner who has had three previous claims or appeals "dismissed on the grounds that [they were] frivolous, malicious, or fail[ed] to state a claim upon which relief may be granted" is barred from bringing any further claims in federal court "unless the prisoner is under imminent danger of serious physical injury"); 42 U.S.C. § 1997e(a) (stipulating that no prisoner can bring a $\S 1983$ action "until such administrative reme. dies as are available are exhausted").

127 This was certainly the case in Jones, in which the appeals court imposed added procedural burdens on top of the PLRA's already onerous exhaustion requirement. See supra text accompanying notes 84-94. And the same was also true in Plata, where the ongoing efforts of the district courts in Plata and Coleman to give the state sufficient opportunity to remedy acknowledged constitutional violations may well have helped to make conditions in the California prisons as dire as they had become by the time the Court heard the case. See supra text accompanying notes 109-11, 120-21.

128 Plata, 131 S. Ct. at 1951 (Scalia, J. dissenting).

129 Id. at 1950. The panel's order required the state to reduce the population of its prisons to 137.5 percent of rated capacity, 
but it made clear that it was up to the state to decide how to achieve that target; if it could build more prisons, for exam. ple, the state could close in on the required capacity without releasing prisoners. See Coleman v. Schwarzenegger, No. CIV S-90-0520 LKK JFM P, at 32-33 (E.D. Cal. Aug. 8, 2009). As it happens, the state has opted for a different strategy, one that will reduce the prisoner population without either releasing people or building more prisons: what it calls "realignment," which entails requiring the county jails to shoulder more of the burden for low-level offenders and parole violators. See Cal. Assembly Bill No. 109 (2011); see also Governor of the State of Cal., Governor Brown Signs Legislation to Improve Public Safety and Empower Local Law Enforcement (Apr. 5, 2011), http://gov.ca.gov/news. php?id=16964.

130 Plata, 131 S. Ct. at 1950 (Scalia, J., dissenting).

131 In this regard, it seems noteworthy that Plata was written by Justice Kennedy. In recent years, Justice Kennedy has joined the progressive wing of the Court-and written the majority opinion-in cases on key sentencing issues, including strik. ing down the death penalty for defendants who committed non-homicide crimes, see Kennedy v. Louisiana, 554 U.S. 407 (2008), or who committed their crimes as juveniles, see Roper v. Simmons, 543 U.S. 551 (2005), and finding life without parole unconstitutional when imposed on juveniles for non-homicide crimes, see Graham v. Florida, $130 \mathrm{~S}$. Ct. 2011 (2010). And even more to the point, Justice Kennedy appears to have taken a personal interest in the American penal system, speaking publicly against excessive sentences, the folly of mass incarceration, and the overcrowding of the California prison system. See, e.g., Carol J. Williams, Justice Kennedy Laments the State of Prisons in California, U.S., L.A. TIMES, Feb. 4, 2010 (reporting on a public address by Justice Kennedy at Pepperdine Law School, in which he "criticized California sentencing policies and crowded prisons" and "expressed obvious dismay over the state of corrections and rehabilitation in the country"). It is hard not to think that Justice Kennedy's growing personal awareness on these issues informed his thinking on this case, and led him to take at face value the facts presented in Plata.

132474 U.S. 193 (1985)

133 Id. at $198-99$ \& n.5.

134 See id. at 204 (observing that hearing officers are "prison officers . . . temporarily diverted from their usual duties," who "work with the fellow employee who lodges the charge against the inmate upon whom they sit in judgment" which means that they are "under obvious pressure to resolve a dis. ciplinary dispute in favor of the institution and their fellow employee").

135 Id. at 206.

136 ld. at 202-06.

137482 U.S. 78, 98-100 (1987).

138 See id. at 97-98 (finding the marriage regulation to be "an exaggerated response to [the claimed] security objectives" and rejecting the "love triangles" justification as lacking any "logical connection" with the regulation, id. at 98).

139518 U.S. 343 (1996).

140 See id. at 362-63. According to Justice Scalia, the state ought to have been given the opportunity in the first instance to develop a plan for bringing its prison law libraries into con stitutional compliance. See id. at 363 (noting that the court, "[h]aving found a violation of the right of access to the courts," should not have "conferred upon its special mas ter, ... rather than upon [state corrections] officials, the responsibility for devising a remedial plan").

141 Id. at 362-63 (quoting Bounds v. Smith, 430 U.S. 817, 818-19, 832-33 (1977)) (internal citations and quotation marks omitted).
142 See Feeley \& Rubin, supra note 3, at 39 (identifying the years 1965 through 1986 as the reform era of federal prisoners' rights).

143416 U.S. 396 (1974). For further discussion of the "reform era" aspects of Martinez, see supra note 3.

144 Procunier, 416 U.S. at 404-05.

145 ld. at 405.

146 See Brown v. Plata, 131 S. Ct. 1910, 1956 (2011) (Scalia, J., dissenting); Johnson v. California, 543 U.S. 499, 529-30 (2005) (Thomas, J., dissenting); McKune v. Lile, 536 U.S. 24, 37 (2002); Shaw v. Murphy, 532 U.S. 223, 229 (2001); Lewis v. Casey, 518 U.S. 343, 386-87 (1996); Thornburgh v. Abbott, 490 U.S. 401, 407-08 (1989); O'Lone v. Shabazz, 482 U.S. 342, 349-50 (1987); Turner v. Safley, 482 U.S. 78, 84-85 (1987); Rhodes v. Chapman, 452 U.S. 337, 351 n.16 (1981); Bell v. Wolfish, 441 U.S. 520, 531, 547 (1979); Houchins v. KQED, Inc., 438 U.S. 1, 8 (1978); Jones v. N.C. Prisoners' Union, Inc., 433 U.S. 119, 126 (1977); Bounds v. Smith, 430 U.S. 817, 835 (1977) (Burger, C.J., dissenting); see also Pell v. Procunier, 417 U.S. 817, 826 (1974) (echoing the language from Martinez in a case decided in the same Supreme Court term). I thank Scott Dewey for his help in identifying the instances in which the Court subsequently relied on this por. tion of Martinez.

147 See FeELEY \& RUBIN, supra note 3, at 30-34 (discussing the institutional justifications routinely invoked by the federal courts in prison law cases during the "hands-off" era).

148 Procunier, 416 U.S. at 404-05.

149 See id. at 405 ("[W]here state penal institutions are involved, federal courts have a further reason for deference to the appropriate prison authorities.").

150 See id. ("[M]ost [prison problems] require expertise, comprehensive planning, and the commitment of resources, all of which are peculiarly within the province of the legislature and executive branches of government.").

151 See id. at 405 n.9 ("T]he capacity of our criminal justice sys. tem to deal fairly and fully with legitimate claims will be impaired by a burgeoning increase of frivolous prisoner complaints.").

152 Lawrence Gene Sager, Fair Measure: The Legal Status of Underenforced Constitutional Norms, 91 HARV. L. Rev. 1212, 1221 (1978).

153 ld. at 1226

154 See, e.g., Giovanna Shay, Ad Law Incarcerated, 14 Berkeley J. CRIM. L. 329, 344-51 (2009) (explaining that many state departments of correction are exempted from some or all of the requirements of their state's administrative proce. dure acts).

155 See, e.g., Chevron, U.S.A., Inc. v. Natural Res. Def. Council, Inc., 467 U.S. 837, 842-43 (1984) (holding that when a court reviews an agency's interpretation of a statute it administers, "[i]f the statute is silent or ambiguous with respect to the specific issue, the question for the court is whether the agen. cy's answer is based on a permissible construction of the statute," id. at 843); Motor Vehicle Mfrs. Ass'n of the U.S. v. State Farm Mut. Auto. Ins. Co., 463 U.S. 29, 40-57 (1983) (conducting a searching review under the Administrative Pro. cedure Act's (APA) "arbitrary and capricious" standard of the Department of Transportation's decision to rescind an auto. mobile safety regulation); Citizens to Pres. Overton Park, Inc. v. Volpe, 401 U.S. 402, 410-20 (1971) (considering what standard of review to apply under the APA to the Secretary of Transportation's decision to route a highway through a park, and concluding that although "the Secretary's decision is entitled to a presumption of regularity," that presumption should not "shield his action from a thorough, probing, in. depth review," id. at 415); see also Stephen Breyer, Judicial Review of Questions of Law and Policy, 38 Admin. L. Rev. 363, 
364-65 (1986) (noting that administrative law doctrine "urges courts to defer to administrative interpretations of regulatory statutes, while also urging them to review agency decisions of regulatory policy strictly")

156 As Giovanna Shay incisively notes, courts applying the Turner test do not distinguish "among types of prison and jail regulations, policies, and rules, creating a one-size-fits-all approach." Shay, supra note 154, at 341. Consequently, "corrections regulations promulgated pursuant to notice-and. comment rulemaking" and "far more informal policies or practices" receive the same (generous) measure of deference afforded by Turner. Id. This practice presents a striking contrast with the normal rules of administrative law, which "indicate[] that courts should defer to agency interpretations that were issued after notice-and-comment rulemaking proceedings and to those that were embodied in adjudications," and that such deference "might be required in other situa. tions," but otherwise "judicial deference to agency interpretations [must] be earned by their persuasive power." Daniel J. Gifford, The Emerging Outlines of a Revised Chevron Doctrine: Congressional Intent, Judicial Judgment, and Administrative Autonomy, 59 AdmIN. L. REv. 783, 804 (2007) (describing United States v. Mead Corp., 533 U.S. 218 (2001)).

157 See, e.g., Michael C. Dorf, Incidental Burdens on Fundamental Rights, 109 HARV. L. REv. 1175 (1996) (analyzing the Court's use of varyingly strict standards of review when considering the constitutionality of incidental burdens on fundamental rights - specifically, free speech, free exercise of religion, and privacy rights); Suzanne B. Goldberg, Equality Without Tiers, 77 S. CAL. L. Rev. 481 (2004) (describing the Court's three-tier Equal Protection framework and proposing a single-standard alternative); Gerald Gunther, The Supreme Court, 1971 Term-Foreword: In Search of Evolving Doctrine on a Changing Court: A Model for a Newer Equal Protection, 86 HARV. L. REV. 1 (1972) (arguing in favor of shifting from the three-tier Equal Protection framework to one requiring "that legislative means must substantially further legislative ends," id. at 20), Kenji Yoshino, The New Equal Protection, 124 HarV. L. REV. 747, 755-63 (2011) (describing the "framework of tiered scrutiny," id. at 755, that the Court employs in its Equal Protection cases).

158 Conversely, looking at the existing constitutional scheme through the lens of prison law may reveal inconsistencies indicating that the broader framework needs rethinking. Either way, the enterprise is sure to be a fruitful one.

159 See supra notes 154-155.

160 See United States v. Carolene Prods. Co., 304 U.S. 144, 152 n.4 (1938).

161 One could readily imagine a defense of lesser constitutional protections for those members of society who have broken the criminal law and thus forfeited equal consideration. Certainly, this view seems implicitly to inform Justice Thomas's view of the matter. See, e.g., Beard v. Banks, 548 U.S. 521, 536-37 (2006) (Thomas, J., concurring in the judgment); Overton v. Bazzetta, 539 U.S. 126, 139 (2003) (Thomas, J., concurring in the judgment). But the notion that constitutional protections may be forfeited by individual actions-particularly by people already subjected to criminal punishment as penalty for crimes committed-is highly contentious, and to the extent that it does help to explain the Court's prisoners' rights juris. prudence in general, it ought at the very least to be surfaced and explicitly defended.

162 For a fascinating study of judicial psychology in the prison law context, see FEELEY \& RUBIN, supra note 3.

163 Jones v. N.C. Prisoners' Union, Inc., 433 U.S. 119, 128 (1977) (quoting Pell v. Procunier, 417 U.S. 817, 827 (1974)).

164 See Whitley v. Albers, 475 U.S. 312, 322-26 (1986); see also text accompanying notes 62-64.

165 Turner v. Safley, 482 U.S. 78, 100 (1987) (Stevens, J., concur. ring in part and dissenting in part). 